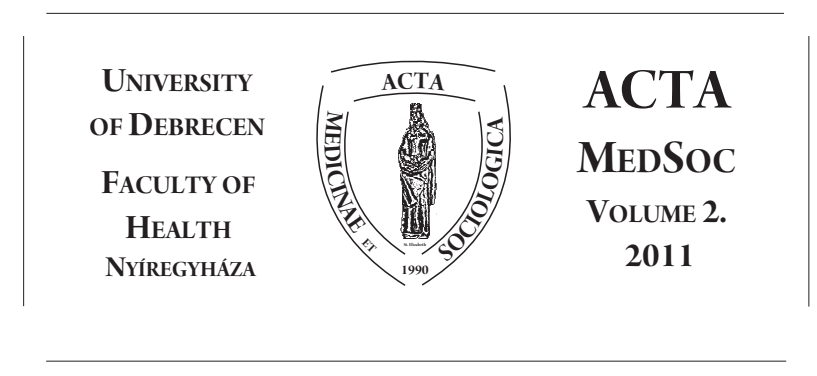

\title{
A szív-érrendszeri betegek ellátásával szerzett tapasztalatok Szabolcs-Szatmár-Bereg megyében
}

\author{
Szegedi János, Gaál Zsolt, \\ Diószeghy Péter, Polgár Péter \\ Jósa András Oktatókórház Nonprofit Kft. \\ Nyíregyháza
}

\begin{abstract}
The cardio-vascular diseases are the first causes of mortality throughout the world, they determine the morbidity indices of the population, the living standards, and they are the most frequent causes of disability. The diseases of the circulatory system present $58 \%$ of the mortality causes of women and $45 \%$ of men within the Hungarian population. The figures of the cardio-vascular diseases are worse in Szabolcs-Szatmár-Bereg county than the Hungarian average. Once the situation had been assessed, an organized cardio-vascular program has been arranged and operated in the county. The author reports on the experiences gained during the arrangement and operation which shall serve as a reference in Hungary.
\end{abstract}

Keywords: cardio-vascular diseases, Szabolcs-Szatmár-Bereg county population DOI: $10.19055 / \mathrm{ams} .2011 .2 / 2 / 2$

A szív- érrendszeri betegségek világszerte az elsô számú haláloki tényezôk, meghatározzák a lakosság morbiditási mutatóit, az életminôséget, a rokkantság leggyakoribb elôidézôii. A magyar lakosság haláloki tényezôi között a keringési rendszer betegségei nôknél 58 \%-ban, férfiakban 45 \%-ban szerepelnek. Szabolcs-Szatmár-Bereg megyében a szív- érrendszeri betegségek mutatói rosszabbak az országos átlagnál. A helyzetfelmérés után került sor a megyében a szervezett szív- érrendszeri program megszervezésére, múködtetésére. A szerző beszámol a szervezéssel, a múködtetéssel kapcsolatos tapasztalatokról, melyek hazai viszonylatban referenciaértékúek. 
Kulcsszavak: szív- érrendszeri betegségek, Szabolcs-Szatmár-Bereg megye

A szív- érrendszeri betegségek világszerte az elsőszámú haláloki tényezôk, meghatározzák a lakosság morbiditási mutatóit, életminôségét és a rokkantság leggyakoribb elóidézői. 1990-ben a világon az 50 millió elhalálozásból 14 millió szívérrendszeri betegségek következtében alakult ki. Elôrejelzések szerint 2020-ban a 68 millió összhalálozáson belül 25 millió ember hal meg szív- érrendszeri betegség következtében $(1,3,4,5,6,7)$.

A magyar lakosság haláloki adatait értékelve a keringési rendszer betegségei a nóknél 58 \%-ban, a férfiaknál 45 \%-ban szerepelnek a halálokok között (2).

\section{Halálozási adatok Magyarországon 2000-2006 átlagában ${ }^{1,2,3}$}

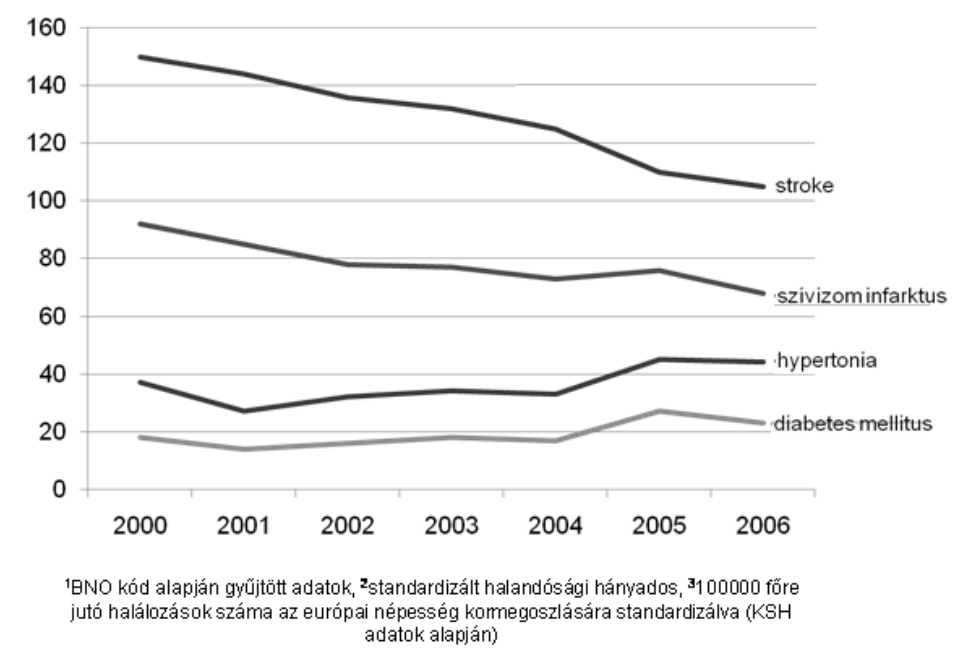

1. ábra. Halálozási adatok Magyarországon 2000-2006 átlagában

A primer coronaria intervenció, a stroke ellátás fejlődésével a szívinfarktus és stroke okozta halálozás csökkent, de a szív- érrendszeri betegségekben komoly szerepet játszó hypertonia és diabetes mellitus halálozása nem javult (1. ábra) (8, $9)$.

A szív- érrendszeri halálozás Magyarországon régiónként is nagy különbséget mutat. Szabolcs-Szatmár-Bereg megye az Észak-alföldi régió tagjaként az országos átlagnál rosszabb mutatókkal rendelkezik (2. ábra) $(10,11,12)$. 


\section{Szív és érrendszeri halálozási adatok Magyarországon}

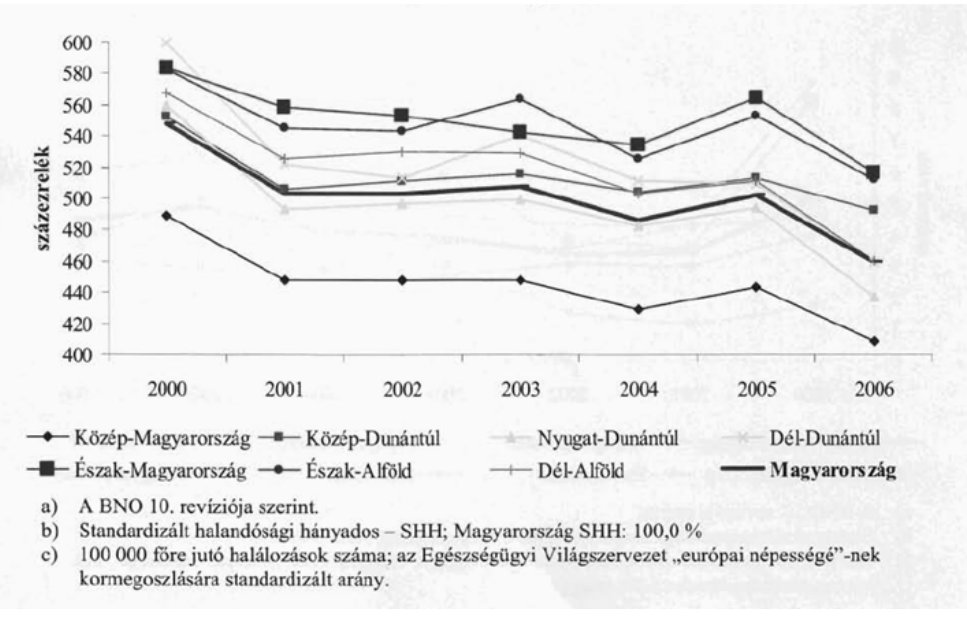

2. ábra. Szív és érrendszeri halálozási adatok Magyarországon

A korai halálozás valószínûsége férfiaknál és nóknél Szabolcs-Szatmár-Bereg megyében az országos átlagnál magasabb (3-4. ábra).

A keringési rendszer betegségeinek standard halálozási mutatói Szabolcs-Szatmár-Bereg megyében rosszabbak az országos átlagnál, de megyén belül is különbségek észlelhetók. Az agyér-betegségek miatti kistérségi halálozás 10.000 lakosra Szabolcs-Szatmár-Bereg megyében magasabb az országos átlagnál (5-6. ábra).

A kardiológiai betegek ellátása a megyében két évtizede szervezett formában történik. A megye négy kórházában coronariaôrző múködik, a progresszív ellátás betegútjai szervezettek. A Hemodinamikai Laboratórium múködése új lehetôséget teremtett az akut coronariabetegek ellátásában. A stroke ellátás feltételrendszere a Jósa András Oktatókórházban van biztosítva (7. ábra).

A megye lakosságának szív- érrendszeri betegségekkel összefüggő morbiditási és mortalitási mutatóinak ismeretében született döntés a Térségi Diagnosztikai és Szưróközponttal kapcsolatos pályázatról, a vaszkuláris betegek ellátásának programjáról.

A program indításakor a legfontosabb célkitûzéseket az alábbiakban foglaltuk össze:

- A megye lakosságának szív- érrendszeri morbiditási és mortalitási mutatóiban az országos, majd a nemzetközi szint elérése. 


\section{A korai (0-65 év közötti) halálozás valószínủsége férfiaknál 2004-2006 évek átlagában}

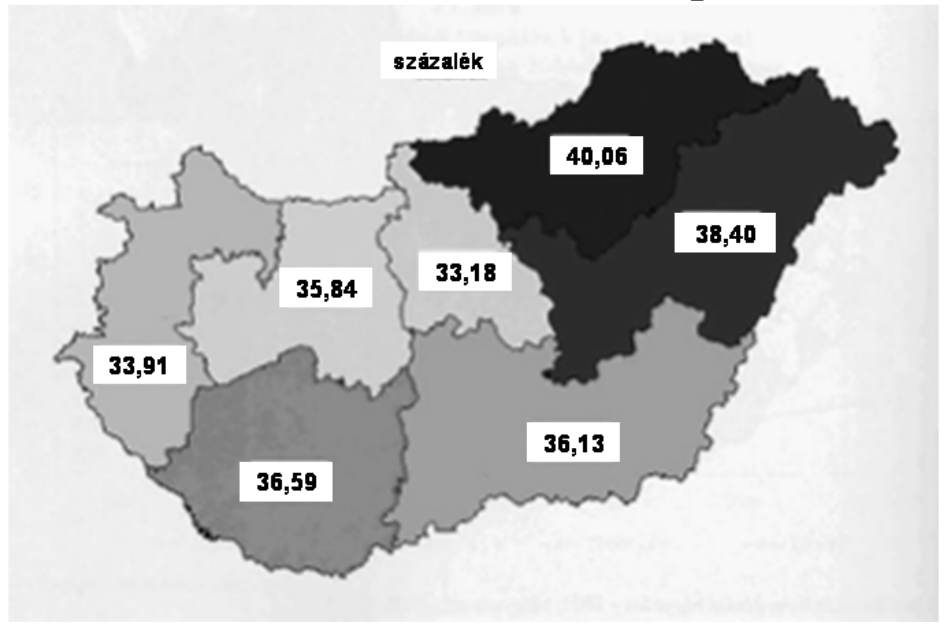

3. ábra. A korai (0-65 év közötti) halálozás valószínűsége férfiaknál 2004-2006 évek átlagában

- A szükségleteknek megfelelő, hosszú távú perspektívával rendelkezô ellátási struktúra kialakítása és múködtetése.

- A rendelkezésre álló humán erőforrás (orvos, egyéb egészségügyi dolgozó), a diagnosztikus és terápiás lehetôségek optimális kihasználása.

- A betegségek kialakulásában szerepet játszó rizikófaktorokat felismerve és kezelve, hatékony megelőzési program múködtetése.

- Szakmailag magas színvonalú, szervezett, költséghatékony ellátás biztosítása.

A Térségi Diagnosztikai és Szüróközpont programjában a feladatok a helyzetfelmérés birtokában kerültek meghatározásra:

- Szûrési programok szervezése, szakmai vezetése.

- A Módszertani Központ múködtetésével a megye epidemiológiai (megbetegedés, halálozás) mutatóinak követése.

- A háziorvosi praxis, a kistérségi központok és a területi kórházak bevonásával a szûréseken kiemelt betegek egységes protokollok alapján végzett kivizsgálása, kezelése, rehabilitációja és gondozása. 


\section{A korai (0-65 év közötti) halálozás valószínűsége nőknél 2004-06 évek átlagában}

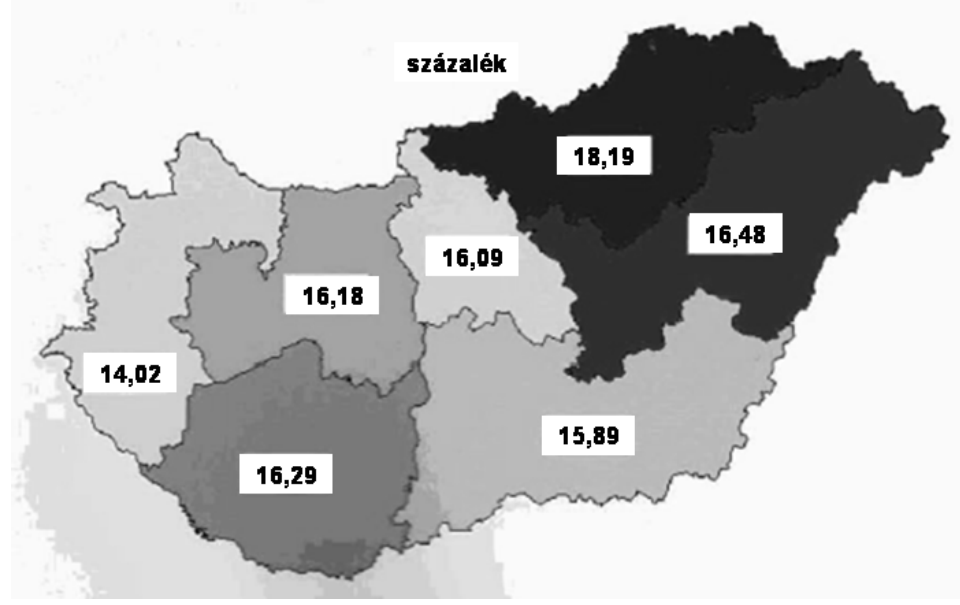

4. ábra. A korai (0-65 év közötti) halálozás valószínûsége nôknél 2004-06 évek átlagában

- A prevenció szakmai irányítása.

- A rendszer múködését biztosító informatikai szolgáltatás biztosítása.

A Vaszkuláris Centrum megvalósítása kapcsán kiemelt feladat volt a betegek ellátásában résztvevók team-munkájának megszervezése. Ennek kapcsán meghatározásra kerültek a vaszkuláris team-ek múködtetésével kapcsolatos elvárások:

- Közös célok megfogalmazása.

- Jó interperszonális kapcsolat az ellátást végzők között.

- Az ellátási folyamat során jó kommunikációs készséggel, meghatározott szerepekkel és kompetencia-határokkal a csapatmunka biztosítása.

- A rendelkezésre álló forrásokhoz adaptált diagnosztikus és terápiás protokollok alkalmazása.

- Segítő/támogató empátiás szemlélet érvényesítése.

- A tevékenység minôségét értékelő indikátorok alkalmazása. 


\section{A férfiak keringési betegségének standardizált halálozási megoszlása 100.000 lakosra kistérségenként Magyarországon}

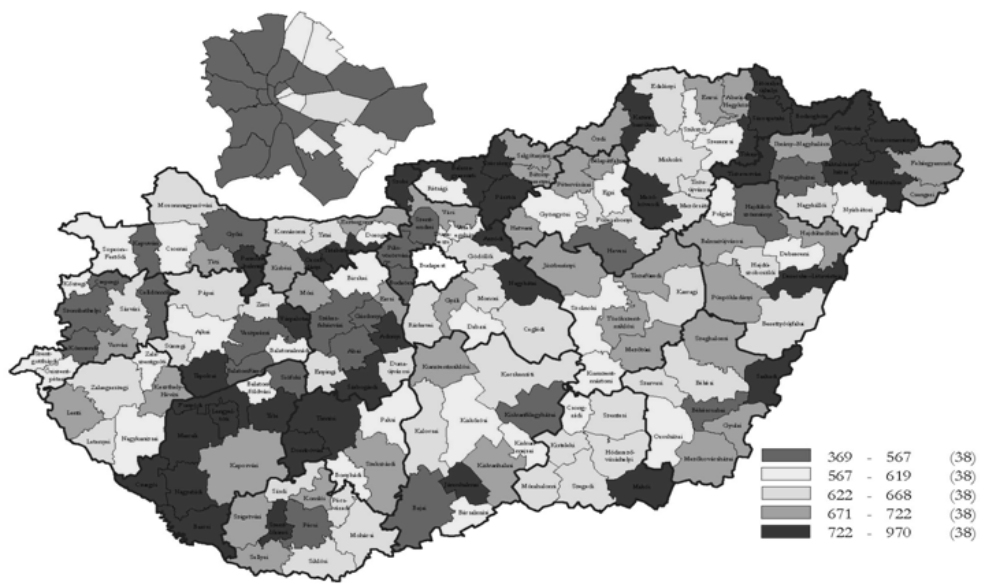

Forrás: KSH, OEK

5. ábra. A férfiak keringési betegségének standardizált halálozási megoszlása 100.000 lakosra kistérségenként Magyarországon

A Térségi Diagnosztikai és Szûróközpont struktúráját a 8. ábra mutatja be.

A Vaszkuláris Centrumon belül biztosított a betegek ellátásához szükséges járóbeteg-szakellátás kapacitása:

coronaria szakrendelés: $\quad 54$ óra

érsebészeti szakrendelés: $\quad 27$ óra

stroke szakrendelés: $\quad 30$ óra

neuroszonológiai szakrendelés: $\quad 30$ óra

belgy. angiológiai szakrendelés: $\quad 30$ óra

rehabilitációs szakrendelés: $\quad 26$ óra

anyagcsere szakrendelés: $\quad 79$ óra

hypertonia szakrendelés: $\quad 30$ óra

$$
\text { összesen: } 306 \text { óra/ hét }
$$

A fekvőbeteg-ellátási kapacitást 12 coronariaốrzô, 150 aktív és 50 rehabilitációs ágy biztosítja.

A Vaszkuláris Centrumon belül múködő Módszertani Központ feladatai:

- Kistérségi mobil szúrések tervezése, szervezése. 


\section{A nök keringési betegségének standardizált halálozási megoszlása 100.000 lakosra kistérségenként Magyarországon}

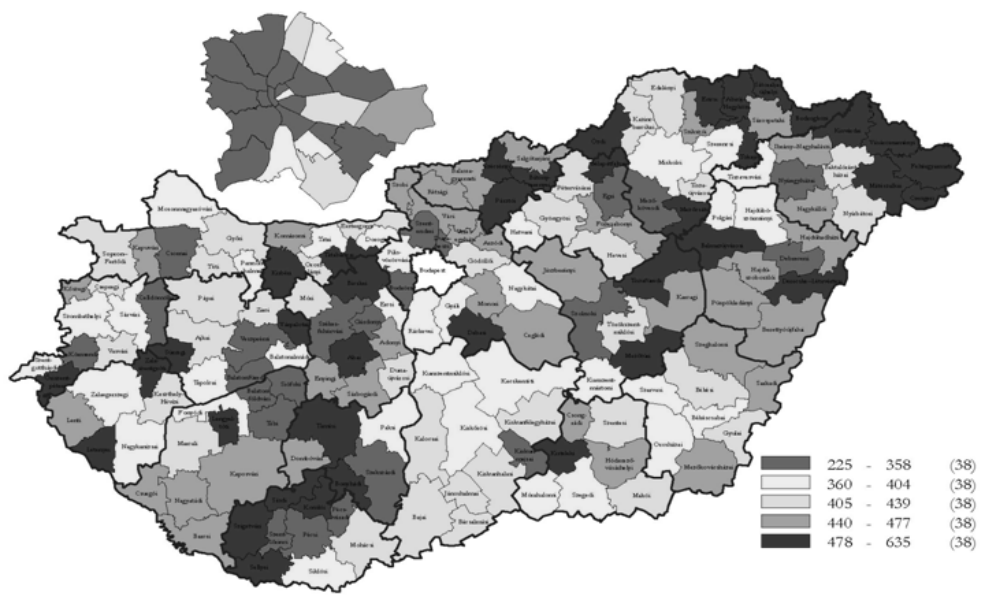

Forrás: KSH, OEK

6. ábra. A nők keringési betegségének standardizált halálozási megoszlása 100.000 lakosra kistérségenként Magyarországon

- A szûrések hatékonyságát biztosító kérdőíves elôszưrések szervezése.

- Szúréseken kiemelt betegek kivizsgálásának biztosítása a Rizikóambulancia bevonásával.

- A szúrések eredményeinek feldolgozása, az epidemiológiai mutatók követése.

- Az epidemiológiai adatok birtokában megelőzési program szervezése, eredményeinek monitorozása.

Az elmúlt időszak tapasztalatai alapján hatékony együttmúködés alakult ki a mobil szúróbusz, a Rizikóambulancia és az érbetegek ellátásával foglalkozó szakrendelések között. A gyakorlatban is sikerült megvalósítani az "egykapus" rendszert. Ennek keretében a szúréseken kiemelt betegek a Rizikóambulanciára kerülnek, ahol a szakorvosi vizsgálat után döntenek az elvégzendô további vizsgálatokról, a beteg további kezeléséról.

Szervezési, építészeti szempontból komoly előnyt jelent, hogy az épület földszintjén múködik a Rizikóambulancia és az érbetegségekkel foglalkozó minden járóbetegszakrendelés (stroke, érsebészet, hypertonológia, diabetológia, lipidológia, kardiológia, angiológia).

Az ambulancia betegforgalma a mobil szưrések eredményeként nô (9. ábra). 


\section{Szabolcs-Szatmár-Bereg megye (560.429 lakos)}



7. ábra. Szabolcs-Szatmár-Bereg megye (560.429 lakos)

Az angiológiai szakrendelés a szüréseken kiemelt lakosok kivizsgálása mellett a praxis, a társszakmák által beutalt artériás és vénás betegségben szenvedő betegek kivizsgálását, a terápiás stratégia meghatározását végzi (10. ábra).

Az invazív angiológiai beavatkozások jelentôsége nó, javítva a betegek prognózisát, életminőségét (11. ábra).

A koszorúér-betegségben, a szívinfarktusban szenvedô betegek ellátásában nagy előrelépést jelentett a Hemodinamikai Laboratórium múködése. Az elektív beavatkozások mellett egyre gyakrabban kerül sor ügyeleti időben is az akut betegek ellátására (12. ábra).

A kardiológiai profilú szakrendelések betegforgalma folyamatosan emelkedik (13. ábra).

A szakrendelés betegforgalmának növekedése jelzi a stroke ellátás jelentôségét (14. ábra). Bevezetésre került a nyaki erek szúkületének ellátására az angioplasztika. A kívánatosnál lassabban, de fokozatosan növekszik az akut ischaemiás stroke ellátásban a thrombolysisek száma.

Ma már általánosan elfogadott, hogy a proteinuria, a vesebetegség, a veseelégtelenség kardiovaszkuláris rizikófaktor. A megyében két évtizede biztosítva van a progresszív nephrológiai ellátás (15. ábra).

A hypertonia népbetegség, ennek megfelelően a betegség incidenciája és prevalenciája is nô (16. ábra). A hypertonia szakambulancia feladata a célszerv-károsodásban szenvedô, a hármas gyógyszer-kombinációval célértéket el nem érô, magas kardio- 


\section{A Térségi Diagnosztikai és Szüröközpont struktúrája}

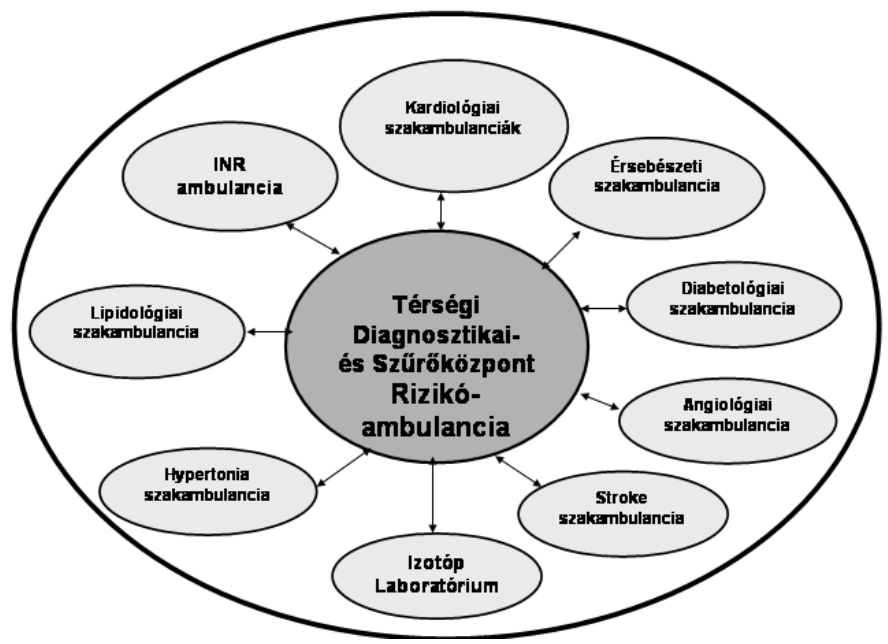

8. ábra. A Térségi Diagnosztikai és Szűrôközpont struktúrája

vaszkuláris rizikójú betegek ellátása.

Az anyagcsere (diabetológiai, lipidológiai) szakrendelés betegforgalma is alátámasztja a cukorbetegség, a zsíranyagcsere-zavar jelentóségét (17. ábra).

Az elmúlt idôszakban a Vaszkuláris Centrum járóbeteg-szakellátásainak betegforgalma folyamatosan emelkedett (18. ábra).

A több mint két éve múködő Vaszkuláris Centrum megvalósítása lehetôséget teremtett arra is, hogy a Megyei Önkormányzat segítségével ezen épülettömbön belül került elhelyezésre a Hemodinamikai Laboratórium, a modern, minden feltételekkel rendelkezô Izotópdiagnosztikai Laboratórium, a 12 ágyas coronariaôrzô részleg, a 10 ágyas belgyógyászati intenzív részleg, a kardiológiai, a stroke és az anyagcsere betegségekkel foglalkozó diabetológiai részleg (19. ábra).

Tapasztalataink alapján az Érközpont jövóképét, feladatait az alábbiakban foglaljuk össze:

- Kiemelt feladat a megelôzés.

- Szürések hatékonyságának javítása, a veszélyeztetett populáció szűrése (informatikai lehetőségek kihasználása).

- Minden orvos-beteg találkozót fel kell használni a szưrésre. 

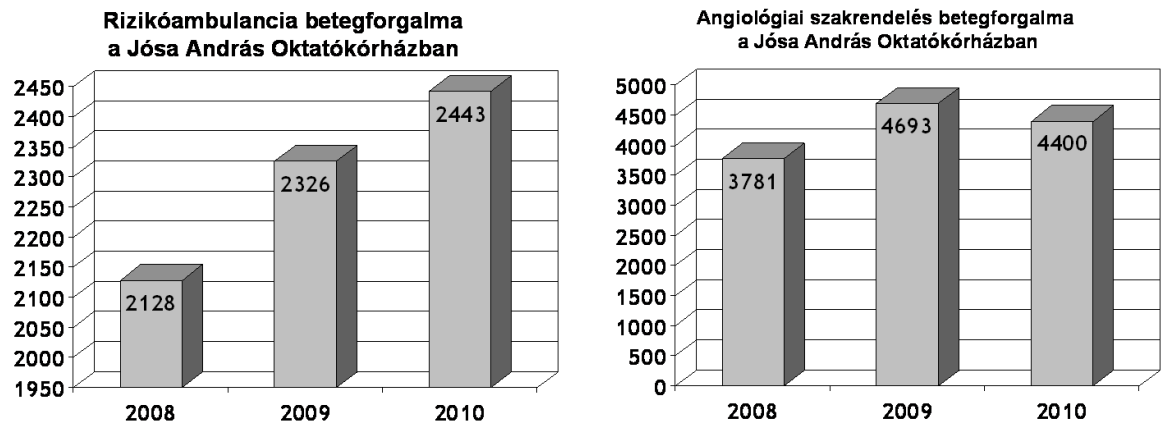

9. ábra. Rizikóambulancia betegforgalma a Jósa András Oktatókórházban

10. ábra. Angiológiai szakrendelés betegforgalma a Jósa András Oktatókórházban

- A szúréseken kiemelt lakosok kivizsgálása a diagnosztikus protokollok alapján.

- A szakmai ajánlások figyelembevételével a terápiás protokollok alkalmazása.

- A betegség felismerésétól a rehabilitáció megkezdése (gondozás, állapotellenôrzés).

- A lakosság morbiditási, mortalitási mutatóinak, életminôségének javítása.

\section{Irodalomjegyzék}

1. Czuriga István: A cardiovascularis betegségek újabb epidemiológiai trendje. Orvosképzés. 2009. S4. 201-366.

2. Kiss István (szerk.): A szív- és érrendszeri betegségek megelőzésének és gyógyításának nemzeti programja. 2006. március.

3. Nemes Attila (szerk.): A Magyar Angiológiai és Érsebészeti Társaság irányelvei. Angiológiai Útmutató. Klinikai Irányelvek Kézikönyve. Medition Kiadó 2009.

4. Czuriga István (szerk.): A kardiológiai betegségek kezelése. Szakmai irányelvek. Kiadó: Documed Kft. 2007. ISSN 1589-9144.

5. Vértes András: Cardiovascularis prevenció perifériás érszúkülletben szenvedô betegek esetében. Orvosi Hetilap. 2007. 148. 28. 1303-1309.

6. G. J. Hankey, P. E. Norman, J. W. Eikelboom: Medical Treatment of Peripheral Arterial Disease. JAMA. 2006. 295. 547-553.

7. De Backer G., Ambrosioni E.., Borch-Johnsen K. et al.: Third Joint Task Force of European and Other Societies on Cardiovascular Disease Prevention in Clinical 

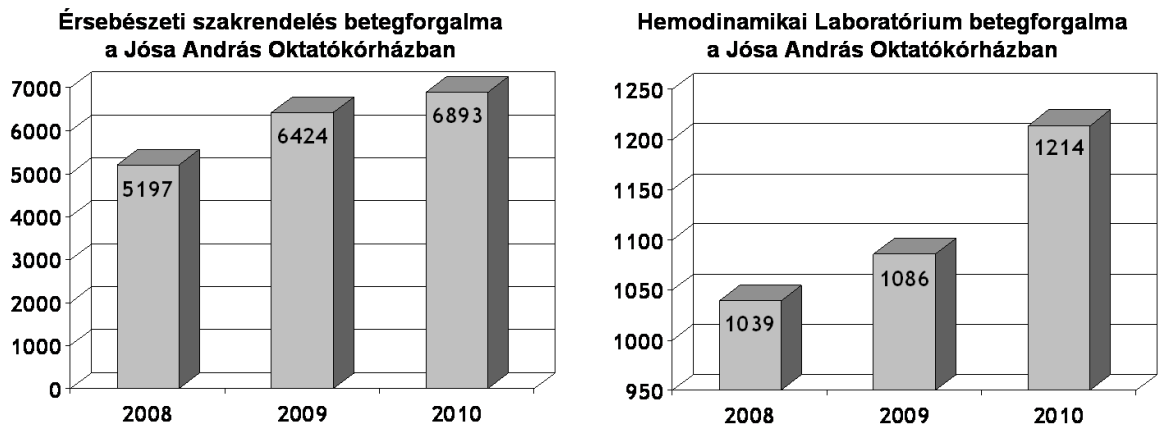

11. ábra. Érsebészeti szakrendelés betegforgalma a Jósa András Oktatókórházban

12. ábra. Hemodinamikai Laboratórium betegforgalma a Jósa András Oktatókórházban

Practice. European guidelines on cardiovascular disease prevention in clinical practice. Third Joint Task Force of European and Other Societies on Cardiovascular Disease Prevention in Clinical Practice. Eur Heart J. 2003. 24. 1601-10.

8. Szomják Edit, Dér Henrietta, Veres Katalin és mtsai: Perifériás érbetegeink klinikai adatainak elemzése, különös tekintetter a kor- és nembeli sajátosságokra, valamint az intervenciós radiológiai beavatkozások késői eredményeire. Magyar Belorvosi Archivum. 2006. 4. 260-266.

9. Nagy Viktor: Egyrôl a kettôre - A cardiovascularis betegség megelőzése. LAM. 2006. 16. (3). 253-256.

10. Meskó Éva (szerk.): Vascularis Medicina. Therápia Kiadó. 2004.

11. Keresztury Gábor és mtsai: Az atherosclerosis korai felismerése és rizikószúrés a Közép-Dunántúlon. A mobil érdiagnosztika. Érbetegségek. 2006. 3. 71-76. 12. Tóth Károly: Érbetegségek epidemiológiája. In: Vascularis Medicina. Meskó Éva (szerk.). Therápia Kiadó. 2004.

Dr. Szegedi János: belgyógyász, nephrológus, hypertológus, osztályvezetô fôorvos

Dr. Gaál Zsolt: belgyógyász, endokrinológus, klinikofarmakológus, foglalkozás-egészségügy szakorvosa, diabetológus, osztályvezetô fôorvos

Dr. habil Diószeghy Péter: neurológus, pszichiáterm klinikai neurofiziológus, osztályvezető fốorvos

Prof. Dr. Polgár Péter: belgyógyász, kardiológus, osztályvezető főorvos

Jósa András Oktatókórház Nonprofit Kft. 4400. Nyíregyháza, Szent István u. 68. 
Kardiológiai profilú szakrendelések betegforgalma a Jósa András Oktatókórházban

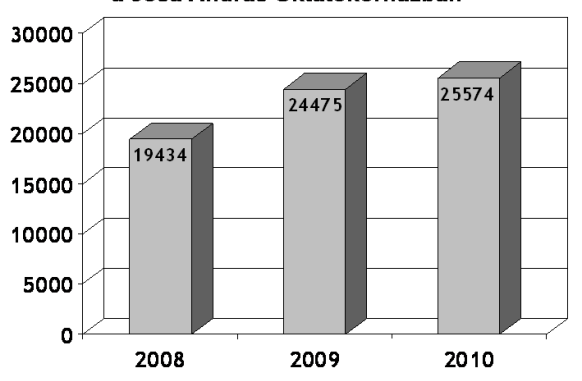

Stroke szakrendelés betegforgalma a Jósa András Oktatókórházban

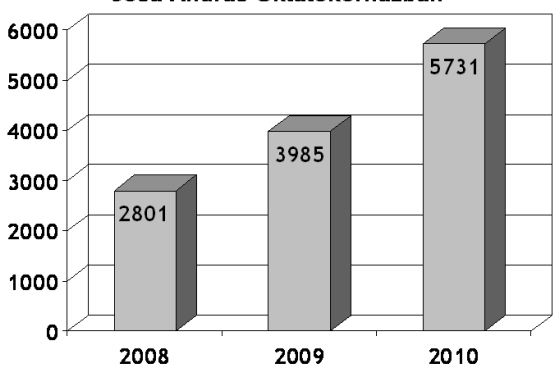

13. ábra. Kardiológiai profilú szakrendelések betegforgalma a Jósa András Oktatókórházban

14. ábra. Stroke szakrendelés betegforgalma a Jósa András Oktatókórházban
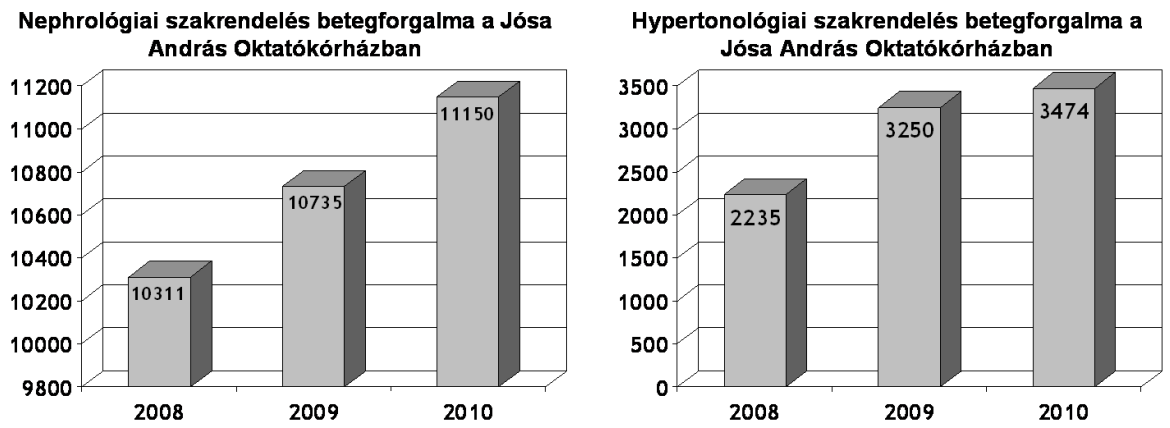

15. ábra. Nephrológiai szakrendelés betegforgalma a Jósa András Oktatókórházban

16. ábra. Hypertonológiai szakrendelés betegforgalma a Jósa András Oktatókórházban 

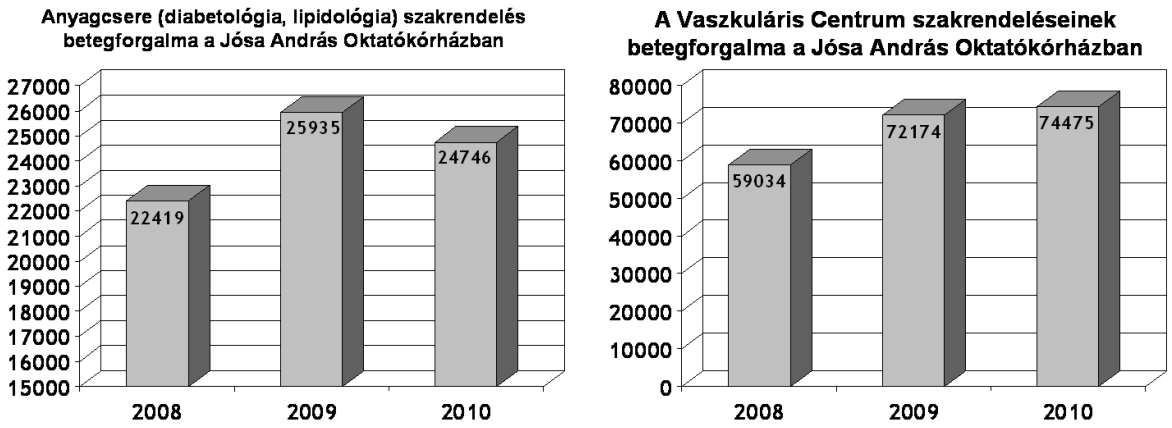

17. ábra. Anyagcsere (diabetológia, lipidológia) szakrendelés betegforgalma a Jósa András Oktatókórházban

18. ábra. A Vaszkuláris Centrum szakrendeléseinek betegforgalma a Jósa András Oktatókórházban

\section{A team-munka megvalósítása 2009-ben Nyíregyházán Az „Érközpont"}

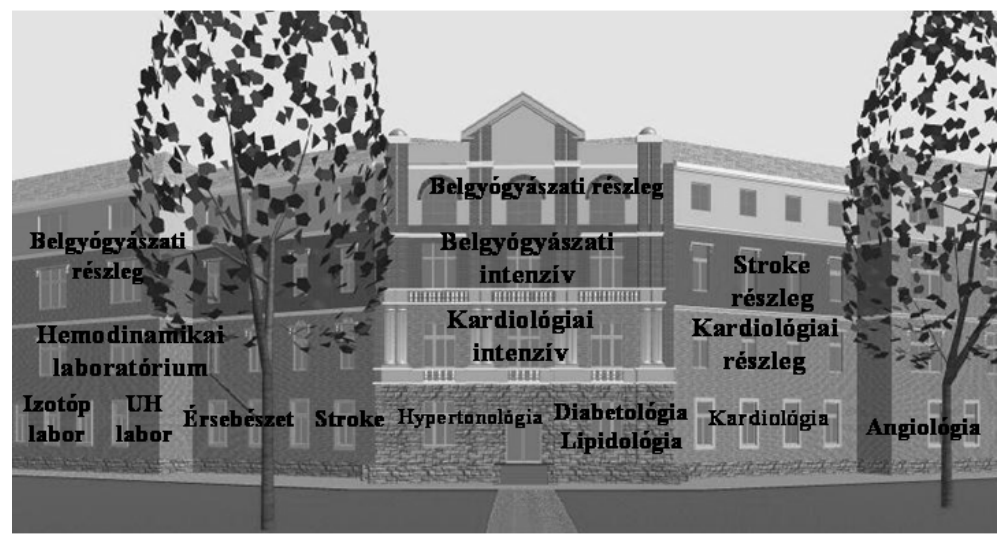

19. ábra. A team-munka megvalósítása 2009-ben Nyíregyházán Az „Érközpont” 